\section{ESA presents united front to competitors at Paris air show}

\section{Paris}

THE 37th international exhibition of aeronautics, the Salon du Bourget, is in full swing at Le Bourget, the site of the former airport outside Paris. It is a time for tubthumping as exhibitors from 31 countries, with more than 200 exhibits, try to persuade buyers that their products are the best. Within the arena, member states of the European Economic Community (EEC) wear their two hats - European and national - somewhat precariously.

With the Ariane series of rocket launchers, and the planned Ariane 5-Hermes shuttle, the European Space Agency (ESA) presents a united front to competitors, particularly the United States, but national pride nevertheless shines through. Determined to have a returnable, manned shuttle in operation by the end of the century, ESA is going ahead with development of the French-inspired Hermes, to be launched by an Ariane 5 rocket, also still on the drawing board.

A full-scale model of Hermes is on display, showing radical design modifications in the light of the Challenger disaster last year. To comply with ESA demands that Hermes should have an ejectable cockpit, in the event of problems with the launcher, its manufacturers, Aérospatiale, have reduced the cockpit from $17 \mathrm{~m}^{3}$ to 5 $\mathrm{m}^{3}$. The number of crew that can be carried has, as a result, been reduced from six to two, with space for a scientific specialist as 'passenger'. The slimmed-down Hermes could be launched from an Ariane 5 with a 21-tonne capacity, whereas the previous version required an unwieldy 25-tonne capacity launcher.

Details of Europe's space programme for the next few years will be discussed at a meeting of ESA partners on 22-23 June and it is expected that some member states will be asked to increase their budget contribution by up to 100 per cent. Apart from Ariane 5 and Hermes, ESA intends to go ahead with construction of its Columbus laboratory module, to be attached to the NASA space station, as well as its Pallas free-flying man-tended laboratory. In an interview with the national daily Le Monde, M. Frédéric d'Allest, president of the French Centre Nationale d'Etudes Spatiales (CNES), expressed the hope that ESA would favour an integrated approach to funding these projects, as Ariane, Hermes and Columbus may not, sensibly, be considered as autonomous entities. To keep pace with a maiden Ariane 5 launch in 1995, a Hermes launch in 1997 and the installation of the first Columbus element in 1996 , the current $£ 1,200$ million annual budget will need to increase to $£ 1,700$
New Delhi

INDIA, which successfully tested indigenously made surface-to-air missiles (SAM) recently, is confident that its missile programme will go ahead despite the seven-nation export ban on critical components and technologies that came into effect on 16 April. The Indian Minister of State for Defence, Mr Arun Singh, told parliament that his scientists were engaged in analysis of the new export controls announced by the United States, Britain, Japan, Italy, West Germany, Canada and France. He said that "with the emphasis given, and the success achieved in indigenization over the years, it is expected that these new controls will not make any significant impact on our programme."

Five different missiles are under development at the Defence Research Development Laboratory (DRDL) in Hyderabad, one of the 40 laboratories under the Defence Research Development Organisation (DRDO).

Trishul, the first Indian-made truck-

\section{Watchmaker rewarded London}

THE unusual choice for this year's Royal Society of Literature's Heinemann Award is Richard Dawkins's The Blind Watchmaker. A science book has never previously won the prize. Dawkins's book, a popular exposition of neo-darwinism, follows The Selfish Gene (1976) and The Extended Phenotype (1981). It was published late last year by Longman in Britain and Norton in the United States and has sold a healthy $40,000-50,000$ copies in hardback.

To his royalty payments Dawkins can now add the Heinemann Award's $£ 3,000$ "for the encouragement of genuine contributors to literature". million by 1995 .

Meanwhile, the Salon du Bourget fuels dreams of what air travel will be like for passengers in the next century. For the French, hopes are that the Avion Grande Vitesse (AGV) will pip its rivals to the post as the hypersonic passenger carrier of the future. Aérospatiale AGV will use statoreactor engine technology to take passengers from a conventional runway to an altitude of $30 \mathrm{~km}$, with speeds up to Mach 5, bringing New York a mere hour away from Paris. AGV's rivals are the US 'Orient Express' and the German Sanger, capable of launching a payload into orbit as well as carrying passengers. The British HOTOL (horizontal take-off and landing).

With its revolutionary, but untested, air-breathing Rolls-Royce RB 546 engine, until recently in competition with Hermes as the vehicle to link up with Columbus, also belongs to this future generation and serves as a reminder that no single European manufacturer is ever likely to be able to finance its pet project without the support of its EEC partners and this may mean a choice has to be made.

Peter Coles

\title{
India confident about its indigenous missile programme
}

mounted SAM, can spring into action in eight seconds and destroy an aircraft $9 \mathrm{~km}$ away. DRDO has conducted four flights of Trishul and hopes to put it into production by 1990 . The ground control equipment that can handle more than one target at a time will be simultaneously produced by the state-owned Bharat Electronics Limited under licence from a company in the Netherlands.

A long-range $(25 \mathrm{~km})$ version of Trishul called Akash, developed at DRDL, is to be test-flown next year. Akash can be fired from truck, aircraft and also from a ship against sea-skimming missiles.

In the next few weeks, DRDL proposes to test its first surface-to-surface missile called Prithvi. It is reported to have a range of $250 \mathrm{~km}$ and to be capable of delivering a one-tonne warhead. It is also the first Indian-made missile with an inertial guidance system. Prithvi is liquidfuelled; Akash and Trishul use solid propellants with very high specific impulse.

The defence scientists have also developed what they call the third-generation fire-and-forget anti-tank missile, called Nag. It is supposed to knock out a tank $4 \mathrm{~km}$ away. The fifth missile under development is called Agni (which means fire). Details of this missile are classified.

According to the Defence Ministry, all these missiles will have entered the production phase by 1993-94 when the US $\$ 1,500$ million missile range at Baliapal on the east coast is expected to be ready.

The Indian missile programme has grown independently of its space programme and DRDO has its own test range, workshops and facilities for producing propellants and electronic systems. It is claimed that DRDO is self-sufficient in most of the critical systems. DRDO will soon start making inertial guidance systems under licence from a French company. 